\title{
PENGARUH PERAN GENDER DAN PEMELIHARAAN LINGKUNGAN MIKRO TERHADAP KESEJAHTERAAN SUBJEKTIF KELUARGA PETANI DATARAN TINGGI
}

\author{
Atika Rahma ${ }^{1^{*}}$, Herien Puspitawati ${ }^{2}$, Tin Herawati ${ }^{2}$ \\ ${ }^{1}$ Program Studi IImu Keluarga dan Perkembangan Anak, Sekolah Pascasarjana, Institut Pertanian Bogor, \\ Bogor 16680, Indonesia \\ ${ }^{2}$ Departemen IImu Keluarga dan Konsumen, Fakultas Ekologi Manusia, Institut Pertanian Bogor, \\ Bogor 16680, Indonesia \\ ${ }^{*}$ E-mail: atika.zae@gmail.com
}

\begin{abstract}
Abstrak
Penelitian ini bertujuan untuk menganalisis pengaruh peran gender dan pemeliharaan lingkungan mikro rumah terhadap kesejahteraan subjektif keluarga petani di Desa Sindangjaya, Kecamatan Cipanas, Kabupaten Cianjur, Provinsi Jawa Barat. Pemilihan responden sebanyak 100 keluarga dilakukan secara purposive. Pengumpulan data dilakukan dengan wawancara dan pengamatan lingkungan rumah. Adapun data yang dikumpulkan meliputi karakteris tik keluarga, karakteristik lingkungan rumah, permasalahan keluarga (ekonomi, lingkungan rumah, dan pertanian), pemeliharaan lingkungan mikro rumah (kebersihan dan kesehatan, pengelolaan pestisida, perlindungan anak, dan pengelolaan pekarangan), pembagian peran gender (publik, domestik, dan sosial kemasyarakatan), dan kesejahteraan subjektif keluarga (fisik, ekonomi, sosial, psikologis, kondisi pekarangan, dan kondisi kebun). Analisis regresi linear berganda menunjukkan bahwa pendapatan keluarga $(\beta=0,222, p<0,05)$, permasalahan keluarga $(\beta=-0,294, p<0,01)$, dan pemeliharaan lingkungan mikro rumah $(\beta=0,250, \quad p<0,01)$ berpengaruh signifikan terhadap kesejahteraan subjektif keluarga. Peningkatan pendapatan keluarga dan pemeliharaan lingkungan mikro yang semakin baik dapat meningkatkan kesejahteraan subjektif keluarga. Peningkatan beban masalah keluarga dapat menurunkan tingkat kesejahteraan subjektif keluarga. Sementara itu, peran gender tidak berpegaruh signifikan terhadap kesejahteraan subjektif keluarga.
\end{abstract}

Kata kunci: keluarga petani, kesejahteraan subjektif keluarga, pemeliharaan lingkungan mikro, peran gender

\section{The Effect of Gender Roles and Micro Environment Maintenance on Subjective Well-Being of Highland Farmer Families}

\begin{abstract}
The study aimed to analyze the effect of gender roles and micro environment maintenance on subjective well-being of farmer families in Sindangjaya Village, Cipanas Sub-District, Cianjur District, West Java Province. Samples as much as 100 farmer families were selected purposively. Data was collected by interview and observation the home environment. The data collected include family characteristics, characteristics of the home environment, family problems (economic, home environment, and agriculture), micro environment maintenance (hygiene and health, pesticide management, children protection, and homeyard management), the division of gender roles (public, domestic, and social community), and family well-being (physical, economic, social, psychological, homeyard conditions, and garden conditions). Multiple regression analys is showed that family income $(\beta=0,222, p<0,05)$, family problems $(\beta=-0,294, p<0,01)$, and micro environment maintenance $(\beta=0,250$, $p<0,01)$ significantly affects the subjective family well-being. Increasing the family income and better of micro environment maintenance can increase the family subjective well-being. Increasing the family problem will reducing the family subjective well-being. Meanwhile, gender roles no significantly effect on subjective family wellbeing.
\end{abstract}

Keywords: farmer families, family subjective well-being, micro environment maintenance, gender roles

PENDAHULUAN

Pertanian memiliki peran strategis dalam pembangunan nasional. Selain beperan penting dalam penyediaan kebutuhan pangan, pertanian juga berkontribusi terhadap Produk
Domestik Bruto (PDB) meskipun nilainya masih rendah. Tahun 2013, kontribusi sektor pertanian terhadap PDB sebesar 14,43 persen, padahal pertanian merupakan sektor yang menyerap tenaga kerja tertinggi yaitu sebanyak 102.375.368 orang atau 41,2 persen (BPS, 
2013). Kondisi yang tidak seimbang antara kontribusi PDB dan jumlah tenaga kerja yang diserap menyebabkan tingkat produktivitas tenaga kerja dan kesejahteraan keluarga yang bekerja di sektor pertanian berada di posisi terendah dibandingkan dengan sektor lainnya seperti sektor industri. Produktivitas dan kesejahteraan petani yang rendah disebabkan oleh beberapa faktor, diantaranya adalah rendahnya tingkat pendidikan, pendapatan, nilai tukar petani, keterbatasan akses terhadap informasi dan sumberdaya, rendahnya wawasan (Soesilo, Sunan, dan Kaluge, 2007), serta rendahnya manajemen keuangan (Skogrand et al., 2010).

Teori struktural fungsional menyatakan bahwa setiap anggota keluarga memiliki peran, fungsi, dan tugasnya masing-masing. Keluarga merupakan sebuah struktur sosial yang terdiri atas jaringan hubungan sosial yang kompleks antara anggota-anggotanya (Marzali, 2006). Pertanian merupakan kegiatan mencari nafkah yang identik dengan peran laki-laki sebagai kepala keluarga. Namun, berdasarkan Statistik Daerah Kecamatan Cipanas (BPS, 2013), jumlah petani perempuan sebesar 37,02 persen dari jumlah petani di Indonesia. Hal ini menunjukkan keterlibatan perempuan pada kegiatan pertanian harus diperhitungkan. Elizabeth (2008) menemukan bahwa peran ganda wanita tani sangat strategis dalam upaya peningkatan produktivitas usaha tani dan pendapatan keluarga serta ketahanan pangan. Selain itu, petani perempuan juga lebih mudah mendapatkan kepercayaan dalam memperoleh pinjaman modal karena petani perempuan lebih kreatif dalam memikirkan keberlangsungan kegiatan pertaniannya (Purnawati, 2009).

Peran perempuan pada keluarga petani juga berkaitan dengan menjaga dan memelihara lingkungan, terutama lingkungan di sekitar keluarga. Deacon dan Firebaugh (1988) menyatakan bahwa sebagai pusat sistem, keluarga dikelilingi oleh subsitem yang terdiri atas lingkungan mikro (fisik dan sosial), lingkungan makro (sistem masyarakat, politik, teknologi, sosial budaya, dan ekonomi), dan lingkungan makro (alami, buatan, biologi dan fisik). Rumah dan pekarangan yang merupakan lingkungan mikro keluarga adalah salah satu kebutuhan dasar manusia. Rumah tidak hanya berfungsi sebagai tempat tinggal tetapi juga sebagai sarana pembinaan keluarga, cerminan harkat, dan martabat penghuninya, serta aset bagi pemiliknya (Undang-undang Republik Indonesia Nomor 1 Tahun 2011 tentang Perumahan dan Kawasan Pemukinan). Rumah juga merupakan salah satu indikator kesejahteraan keluarga. Oleh karena itu, setiap keluarga dituntut untuk berperan dan bekerja sama dalam rangka menjaga kebersihan, kenyaman, dan keamanannya.

Pada keluarga tradisional, peran pemeliharaan rumah lebih banyak dilakukan oleh perempuan. Perempuan adalah pihak yang memiliki akses dan kontrol terhadap kegiatan pemelihara rumah. Perempuan juga lebih memahami dalam mengelola rumah tangga, mengelola biaya hidup sehari-hari, memahami kondisi dan kebutuhan ruang dalam rumah serta sarana dan prasarana yang dibutuhkan di lingkungan perumahannya (Puspitawati, 2013). Pada keluarga petani, rumah juga berfungsi sebagai tempat penyimpanan alat dan bahan pertanian. Oleh karena itu, diperlukan kerja sama antara lakilaki dan perempuan dalam kegiatan pemeliharan lingkungan rumah, termasuk informasi tentang dampak dari alat dan bahan pertanian serta tata cara penyimpanan yang mempertimbangkan keamanan anggota keluarga. Secara khusus penelitian ini bertujuan untuk menganalisis karakteristik lingkungan rumah, permasalahan keluarga, pemeliharaan lingkungan mikro rumah, pembagian peran gender, dan kesejahteraan subjektif keluarga petani dataran tinggi. Selanjutnya, penelitian ini juga bertujuan menganalisis pengaruh karakteristik lingkungan rumah, permasalahan keluarga, pemeliharaan lingkungan mikro rumah, dan pembagian peran gender terhadap kesejahteraan subjektif keluarga petani dataran tinggi.

\section{METODE}

Penelitian ini merupakan bagian dari
proyek Integrated Pest Management Collaborative Research Support Program (IPMCRSP) tahun 2012 yang merupakan kerja sama antara USAID, Clemson University-USA, dan Virginia-Tech University-USA dengan Institut Pertanian Bogor. Desain penelitian ini adalah cross sectional. Penelitian dilakukan di Kecamatan Cipanas, Kabupaten Cianjur, Provinsi Jawa Barat. Kecamatan Cipanas dipilih secara purposive dengan pertimbangan sebagai berikut: (1) merupakan lokasi pertanian dataran tinggi, (2) merupakan lokasi kegiatan IPM-CRSP, (3) sebagian besar rumah memiliki pekarangan yang dimanfaatkan sebagai lahan tanaman hias, (4) berada di lokasi yang strategis, yaitu dekat pasar Cipanas, jalur regional (Jakarta-Bogor-Bandung) dan kawasan wisata Kebun Raya Cibodas, serta Istana Cipanas, serta 5) merupakan salah satu wilayah agropolitan, yaitu kota pertanian yang 
tumbuh dan berkembang karena berjalannya sistem dan usaha agribisnis serta mampu melayani, mendorong, menarik, menghela kegiatan pembangunan pertanian (sektor usaha pertanian dalam artian luas) di wilayah sekitarnya.

Responden adalah keluarga petani yang memiliki perkarangan dan memanfaatkannya secara produktif. Responden yang terlibat berjumlah 100 keluarga petani yang dipilih secara purposive. Responden dalam penelitian ini berjumlah 200, terdiri atas 100 istri dan 100 suami. Data yang dikumpulkan adalah data primer yang diperoleh melalui wawancara dan pengamatan. Data yang dikumpulkan melalui wawancara terdiri atas karakteristik keluarga, permasalahan keluarga, pemeliharaan lingkungan mikro, peran gender, dan kesejahteraan subjektif keluarga, sedangkan pengamatan dilakukan untuk mengidentifikasi karakteristik lingkungan rumah.

Karakteristik keluarga yang diukur meliputi usia suami dan istri, lama pendidikan suami dan istri, dan pendapatan keluarga. Usia suami dan istri diukur berdasarkan tahun kemudian dikelompokkan berdasarkan Hurlock (1998) yaitu: (1) dewasa awal (20-40 tahun), (2) dewasa madya (40-60 tahun) dan (3) dewasa akhir (>60 tahun). Pendidikan suami dan istri diukur berdasarkan lama pendidikan yang sudah diselesaikan (tahun), kemudian dikelompokkan menjadi: (1) tidak sekolah, (2) tidak tamat SD, (3) tamat SD, (4) tidak tamat SMP, (5) tamat SMP, (6) tidak tamat SMA, dan (7) tamat SMA. Jumlah anggota keluarga merupakan seluruh anggota keluarga yang masih tinggal satu atap, selanjutnya dikelompokkan menjadi keluarga kecil $(\leq 4$ orang), sedang (5-7 orang), dan besar $(\geq 8$ orang). Pendapatan keluarga diukur dengan menghitung pendapatan seluruh anggota keluarga yang bekerja di sektor formal maupun nonformal selama satu bulan (Rupiah). Selanjutnya pendapatan keluarga dikelompokkan berdasarkan UMR (Upah Minimum Regional) Kabupaten Cianjur Tahun 2012, yaitu $\mathrm{Rp} 876.500,0$.

Pengukuran karakteristik lingkungan rumah merupakan modifikasi dari Keputusan Menteri Kesehatan Nomor 829/MENKES/SK/VII/1999 tentang Persyaratan Kesehatan Perumahan yang mencantumkan parameter untuk menentukkan rumah sehat. Parameter ini meliputi tiga komponen, yaitu komponen fisik rumah, sarana sanitasi, dan perilaku penghuni. Pada penelitian ini, karakteristik lingkungan rumah dikelompokkan menjadi dimensi kondisi fisik (7 pertanyaan), sarana sanitasi (5 pertanyaan), dan karakteristik pekarangan (3 pertanyaan). Setiap pertanyaan memiliki tiga jawaban (skala ordinal). Hasil indeks kemudian dikelompokkan menjadi rendah $(0,0-50,0 \%)$, sedang (51,0$75,0 \%)$, dan tinggi $(>75,0 \%)$.

Pertanyaan variabel permasalahan keluarga merupakan hasil modifikasi dari Puspitawati (2006). Permasalahan keluarga dikelompokkan menjadi tiga dimensi yaitu ekonomi (2 pertanyaan), lingkungan rumah (8 pertanyaan) dan pertanian (3 pertanyaan). Responden menjawab pertanyaan dengan jawaban 1=tidak bermasalah, 2=cukup bermasalah dan $3=$ sangat bermasalah. Jawaban kemudian dijumlahkan dan diubah ke dalam indeks dan dikelompokkan menjadi rendah $(0,0-50,0 \%)$, sedang $(51,0-75,0 \%)$, dan tinggi $(>75,0 \%)$. Nilai reliabilitasnya adalah 0,790 , sedangkan validitas isi berkisar antara 0,388 sampai 0,703 .

Pemeliharaan lingkungan mikro berkaitan dengan kegiatan responden dalam melakukan aktivitas kebersihan dan kesehatan (5 pertanyaan), pengelolaan pestisida (4 pertanyaan), perlindungan anak (3 pertanyaan) dan pekarangan (2 pertanyaan). Pilihan jawaban pertanyaan terdiri atas $1=$ tidak pernah, 2=jarang sekali, $3=$ kadang-kadang atau 4=sering/selalu. Jawaban kemudian dijumlahkan dan diubah ke dalam indeks dan dikelompokkan menjadi rendah $(0,0-50,0 \%)$, sedang $(51,0-75,0 \%)$, dan tinggi $(>75,0 \%)$. Nilai reliabilitasnya adalah 0,636, sedangkan validitas isi berkisar antara 0,095 sampai 0,647.

Pengukuran pembagian peran gender menggunakan teknik analisis Moser dan Harvard, yaitu melalui analisis profil tiga peran (triple roles). Tiga peran tersebut adalah peran produktif, domestik, dan kemasyarakatan. Adapun pertanyaan merupakan modifikasi dari Puspitawati (2009). Pada penelitian ini, peran produktif atau peran usaha tani berkaitan keterlibatan suami dan istri dalam akses (7 pertanyaan), kontrol (7 pertanyaan), dan manfaat (7 pertanyaan) dari usaha tani, kegiatan di kebun (11 pertanyaan) dan pekarangan (6 pertanyaan), pengelolaan keuangan usaha tani (8 pertanyaan) dan pengelolaan pestisida (4 pertanyaan). Peran domestik meliputi keterlibatan suami istri dalam kegiatan pemenuhan pangan keluarga (3 pertanyaan), pengasuhan dan pendidikan anak (3 pertanyaan), pemeliharaan rumah tangga (7 pertanyaan), kesehatan keluarga (2 pertanyaan), dan pengelolaan keuangan 
keluarga (9 pertanyaan). Sementara itu, peran sosial kemasyarakatan adalah keterlibatan suami dan istri pada kegiatan arisan, pengajian, rapat desa, dan kerja bakti. Jawaban pembagian peran gender terdiri atas $1=$ suami saja, 2=suami dominan, $3=$ suami dan istri, $4=$ =istri dominan, $5=$ =istri saja dan $6=$ anak. Selanjutnya jawaban tersebut di recode menjadi 1 =suami atau istri saja, 2=suami atau sitri dominan dan $3=$ suami dan istri. Jawaban kemudian dijumlahkan dan diubah ke dalam indeks dan dikelompokkan menjadi rendah $(0,0-50,0 \%)$, sedang $(51,0-75,0 \%)$ dan tinggi $(>75,0 \%)$. Nilai reliabilitasnya adalah 0,916 , sedangkan validitas isi berkisar antara 0,089 sampai 0,841 .

Pertanyaan dalam pengukuran kesejahteraan keluarga subjektif terdiri atas enam dimansi, yaitu kesejahteraan fisik (10 pertanyaan), ekonomi (11 pertanyaan), sosial (13 pertanyaan), psikologis (9 pertanyaan), keadaan kebun (4 pertanyaan) dan pekarangan (4 pertanyaan). Setiap pertanyaan diberikan jawaban 1=tidak puas, 2=cukup puas dan $3=$ puas. Jawaban kemudian dijumlahkan dan diubah ke dalam indeks dan dikelompokkan menjadi rendah $(0,0-50,0 \%)$, sedang $(51,0$ $75,0 \%$ ) dan tinggi (>75,0\%). Nilai reliabilitasnya adalah 0,740 , sedangkan validitas isi berkisar antara 0,279 sampai 0,686 .

Data dianalisis secara deskriptif dan inferensial. Analisis deskriptif yang digunakan adalah nilai rata-rata, simpangan baku, maksimum, dan minimum. Statistik inferensial yang digunakan adalah korelasi Pearson dan regresi linear berganda. Uji korelasi Pearson untuk menganalisis hubungan antara variabel karakteristik keluarga, karakteristik lingkungan rumah, permasalahan keluarga, pemeliharaan lingkungan mikro, peran gender, dan kesejahteraan subjektif. Selanjutnya, uji regresi linear berganda untuk menganalisis pengaruh karakteristik keluarga, karakteristik lingkungan rumah, permasalahan keluarga, pemeliharaan lingkungan mikro, peran gender terhadap kesejahteraan subjektif.

\section{HASIL}

\section{Karakteristik Keluarga}

Rata-rata usia suami adalah 45,3 tahun, dengan usia minimum 25 tahun dan usia maksimum 80 tahun. Rata-rata usia istri adalah 38,7 tahun dan usia minimum 20 tahun serta usia maksimum 79 tahun. Berdasarkan tingkat pendidikan, baik suami maupun istri tamat sekolah dasar dengan rata-rata lama pendidikan suami adalah 5,5 tahun dan istri 5,1 tahun. Jumlah anggota keluarga paling sedikit adalah 2 orang dan terbanyak adalah 11 orang per keluarga serta sebanyak termasuk ke dalam keluarga sedang (5-7 orang) dengan rata-rata terdapat 5 orang per keluarga. Sumber pendapatan keluarga berasal dari kebun, pekarangan, dan hasil berwirausaha. Rata-rata pendapatan terbesar yang berasal dari kegiatan wirausaha, yaitu $\mathrm{Rp}$ 1.384.318,0 sedangkan rata-rata pendapatan dari kebun dan pekarangan adalah $\mathrm{Rp} 890.278,0$ dan $\mathrm{Rp}$ 320.323,2. Berdasarkan UMR Kabupaten Cianjur Tahun 2012 yaitu Rp 876.500,0, maka sebanyak 52 persen responden berpendapatan di bawah UMR dan 48 persen memiliki pendapatan di atas UMR.

\section{Permasalahan Keluarga}

Berdasarkan dimensi ekonomi, lebih dari separuh responden menyatakan hutang tidak bermasalah, sedangkan kecukupan uang cukup bermasalah. Hasil analisis dimensi lingkungan rumah, lebih dari separuh responden menyatakan tidak bermasalah berkaitan dengan tempat tinggal, kesehatan keluarga akibat pestisida, transportasi, tempat pembuangan sampah, saluran air, penampungan air, kebersihan lingkungan, dan pembuangan sampah sembarangan. Meskipun demikian, terdapat sepertiga responden menyatakan pembuangan sampah sembarangan cukup bermasalah. Lebih dari separuh responden menyatakan dimensi pertanian seperti hasil penyemprotan pesitsida, kondisi tanaman dipekarangan, dan penyuluhan serta pendampingan pertanian tidak bermasalah. Namun, masih terdapat 44 persen responden yang menyatakan kondisi tanaman di pekarangan cukup bermasalah, dikarenakan hama dan penyakit tanaman. Sejalan dengan Bertham, Ganefianti, dan Andani (2011) bahwa permasalahan usaha tani adalah hama dan penyakit. Berdasarkan hasil analisis, tingkat permasalahan sebagian besar responden termasuk rendah, artinya bahwa secara umum permasalahan ekonomi, lingkungan rumah dan pertanian di lokasi penelitian dinilai tidak bermasalah, kecuali berkaitan dengan kecukupan uang, pembuangan sampah sembarangan, dan kondisi tanaman pekarangan.

\section{Karakteristik Lingkungan Rumah}

Berkaitan dengan komponen fisik rumah, hampir seluruh keluarga responden memiliki dinding tembok, atap genteng, lantai keramik atau plester semen rata-rata jumlah ruang dan 
jendela adalah 6 buah. Rata-rata luas dapur rumah adalah $6,16 \mathrm{~m}^{2}$. Selain sebagai tempat peralatan rumah tangga, dapur juga digunakan untuk menyimpan alat dan bahan pertanian, seperti alat penyemprot, pestisida, pupuk dan bibit. Lebih dari seperempat responden menyimpannya di ruang bagian atap dapur atau bersebelahan dengan peralatan rumah tangga lainnya. Alasannya adalah kekhawatiran responden akan hilangnya barang-barang tersebut jika di simpan di luar rumah dan tidak memiliki ruang lain yang dapat digunakan sebagai gudang.

Berkaitan dengan sarana sanitasi, hampir seluruh responden menggunakan mata air pegunungan dan telah memiliki kamar mandi sendiri. Namun, pengolahan sampah masih bermasalah karena sebagian besar responden membuang sampah rumah tangga di pekarangan dan di bakar. Responden mengeluhkan minimnya fasilitas Tempat Pembuangan Sementara (TPS) di lokasi penelitian, sehingga membakar sampah adalah alternatif yang dipilih responden.

Luas pekarangan responden dikelompokkan menjadi tiga kelompok, yaitu sempit, sedang, dan luas. Hasil analisis menemukan bahwa sebagian besar keluarga memiliki pekarangan yang sempit, dengan luas minimum $1 \mathrm{~m}^{2}$ dan maksimum $600 \mathrm{~m}^{2}$. Namun, keterbatasan lahan tidak menjadi hambatan bagi keluarga untuk membudidayakan tanaman bunga potong seperti ruskus, buntut bajing, siklok, roskol, angrek, grasena, sansiviera, bonsai atau berternak kelinci. Berdasarkan hasil analisis, dapat disimpulkan bahwa responden memiliki lingkungan rumah yang cukup baik $(79,0 \%)$.

\section{Pemeliharaan Lingkungan Mikro Rumah}

Pemeliharaan lingkungan mikro rumah yang dilakukan oleh sebagian besar responden $(>71,0 \%)$ melakukan kegiatan pemeliharaan kebersihan dan kesehatan lingkungan rumah dengan cara mengajarkan anak membuang sampah pada tempatnya, tidak membuang sampah ke halaman, dan tidak menggunakan air untuk memasak dan mandi dari satu wadah. Namun lebih dari separuh responden $(62,0 \%)$ sering membakar sampah dipekarangan dan menyimpan tempat sampah rumah tangga di dalam rumah. Rata-rata responden menimbun sampah di tempat sampah rumah tangga adalah selama 2-3 hari. Perilaku menjaga kebersihan dan kesehatan juga dilakukan dengan menentukan jarak antara makanan dengan sumber sampah dan pestisida. Hampir separuh responden $(47,0 \%)$ menyimpan tempat pembuangan sampah lebih dari 10 meter dari penampungan air. Sementara itu, jarak antara tempat sampah dengan tempat masak, tempat sampah dengan meja makan, tempat masak dengan tempat menyimpan pestisida, dan meja makan dengan tempat menyimpan pestisida antara satu hingga lima meter $(>38,0 \%)$.

Pengelolaan pestisida dilakukan dengan cara tidak pernah mencuci alat pestisida di tempat mencuci piring dan pakaian serta tidak membuang limbah pestisida ke sungai dan tempat sampah (>80,0\%). Pembuangan yang tidak benar selain dapat mencemari lingkungan juga merupakan potensi bagi orang untuk terpapar secara tidak langsung dengan pestisida (Adriyani, 2006). Bentuk perlindungan terhadap anak dari bahaya pestisida (>80,0\%) ditunjukkan dengan selalu menjauhkan pestisida dari jangkauan anak, anak tidak pernah bermain alat penyemprot pestisida, dan anak tidak pernah berada di dekat bapak saat sedang menyemprot tanaman dengan pestisida.

Pengelolaan pekarangan dilakukan dengan sering menyapu halaman setiap hari $(88,0 \%)$ dan memanfaatkan pekarangan sehingga dapat berfungsi secara ekonomi dan estetika. Lebih dari separuh responden selalu merencanakan terlebih dahulu jenis tanaman yang akan ditanam. Pertimbangan dalam menentukkan jenis tanaman adalah modal yang diperlukan, besarnya keuntungan, lama tanam, biaya perawatan dan pemasaran, sehingga tanaman yang paling banyak dipilih warga adalah ruskus, siklok, buntut bajing, grasena dan roskol. Tanaman tersebut memiliki harga jual Rp300,00 per batang. Meskipun harganya relatif murah, namun dalam hal penjualan tanaman tersebut memberikan pemasukkan yang rutin, sekurang-kurangnya seminggu sekali. Masyarakat juga tidak perlu upaya keras untuk memasaran tanaman tersebut, karena pembeli akan datang sendiri kepada mereka. Hasil analisis menunjukkan bahwa lebih dari separuh responden $(71,0 \%)$ melakukan pemeliharaan lingkungan mikro rumah dengan cukup baik. Responden telah melakukan kegiatan pengelolaan pestisida, melindungi anak dari pestisida dan mengelola pekarangan dengan baik, namun kurang menjaga kebersihan dan kesehatan lingkungan rumah.

\section{Pembagian Peran Gender}

Kegiatan produktif atau usaha tani. Akses dan kontrol kegiatan usaha tani yang terdiri atas input produksi, teknologi pertanian 
training keterampilan, informasi harga-harga, dan pemasaran produk-produk pertanian, organisasi usaha tani serta kepemilikan lahan didominasi oleh suami. Sari, Purnomo, dan Rahayu (2009) akses dan kontrol terhadap sumberdaya ekonomi masih didominasi oleh suami, hal ini dikarenakan suami lebih berperan dalam memenuhi kebutuhan hidup keluarga. Meskipun kegiatan pertanian lebih banyak dilakukan oleh suami, namun manfaat dari usaha tani dirasakan oleh suami dan istri.

Secara umum, kegiatan usaha tani di kebun dan pekarangan didominasi oleh suami. Adapun kegiatan yang dilakukan suami saja adalah pembelian bibit tanaman sayuran dan bunga potong ( $>49,0 \%)$, mempersiapkan lahan $(45,7 \%)$, penggunaan peralatan pertanian $(58,5 \%)$, menanam tanaman (kebun 48,4\%; pekarangan $34,4 \%$ ), pemupukan (kebun 51,6\%; pekarangan $33,7 \%$ ), dan penyiangan di kebun $(47,5 \%)$. Hal ini sejalan dengan Priyadi (2005) bahwa kegiatan pengolahan lahan, penanaman, dan pemupukan lebih banyak dilakukan oleh laki-laki. Kondisi tersebut didasarkan pada pemahaman bahwa tenaga kerja pria yang lebih kuat, sehingga sangat tepat untuk keperluan mencangkul atau pun mengoperasikan traktor. Suami juga mendominasi kegiatan usaha tani dikebun $(>42,0 \%)$ seperti membuat saluran air, pemanenan, membersihkan sayur, mengikat atau mengemas sayur, dan memasarkan sayuran.

Adapun kegiatan usaha tani yang dilakukan secara bersama-sama (suami dan istri) adalah memanfaatkan pekarangan $(34,0 \%)$, merencanakan jenis komoditi tanaman di kebun (47,5\%), menyiangi tanaman di pekarangan $(30,5 \%)$, dan pengelolaan keuangan usaha tani (Puspitasari, Puspitawati, Herawati, 2013). Meskipun pihak yang menerima uang hasil penjualan adalah suami $(41,1 \%)$, namun kegiatan mengelola, merencanakan, membelanjakan, mencatat, mengontrol, dan mengevaluasi keuangan usahatni dilakukan bersama-sama.

Kegiatan usaha tani yang berkaitan dengan pestisida seluruhnya juga dilakukan oleh suami seperti membeli pestisida $(64,2 \%)$, menyemprot pestisida $(93,0 \%)$, membersihkan peralatan pestisida $(77,9 \%)$, membuang wadah pestisida $(74,2 \%)$, dan menyimpan pestisida $(64,3 \%)$. Hal ini diduga karena suami lebih memiliki informasi tentang pestisida baik melalui kelompok tani atau pun dari penyuluhan. Pembagian peran untuk kegiatan usaha tani termasuk kategori sedang. Hal ini berarti bahwa sudah ada kerja sama yang baik antara suami dan istri dalam melakukan kegiatan usaha tani.

Kegiatan domestik. Kegiatan domestik yang diukur pada penelitian ini meliputi pemenuhan pangan keluarga, pengasuhan dan pendidikan anak, pemeliharaan rumah tangga, kesehatan keluarga serta pengelolaan keuangan keluarga. Secara umum, kegiatan domestik lebih banyak dilakukan oleh istri saja, seperti pemenuhan pangan keluarga (>46,9\%) dan mengasuh anak (55,7\%). Kegiatan pemeliharaan rumah tangga juga dilakukan ibu saja $(>58,0 \%)$ seperti mencuci pakaian dan piring, menyetrika, menyapu, mengambil air, membersihkan rak piring serta mengatur kegiatan rumah tangga. Hasil ini sejalan dengan penelitian Puspitawati dan Fahmi (2008) bahwa kegiatan yang berhubungan dengan mengurus anak dan memelihara rumah tangga lebih banyak dilakukan oleh istri. Sementara itu, keterlibatan suami dan istri ditunjukkan pada membuat keputusan pendidikan anak (>47,2\%) dan kesehatan keluarga $(>35,4 \%)$.

Kegiatan pengelolaan keuangan keluarga $(>31,0 \%)$ seperti menentukan pengeluaran untuk pangan, membeli pakaian santai keluarga, belanja kebutuhan sehari-hari, dan mengontrol pengeluaran keuangan keluarga adalah dilakukan istri saja. Sementara itu, kerja sama suami dan istri dalam kegiatan keuangan keluarga ditunjukkan dalam hal mengelola uang keluarga (34,0\%), memutuskan untuk membelanjakan uang keluarga $(30,0 \%)$, dan mencari solusi permasalahan keuangan $(67,7 \%)$.

Berdasarkan hasil analisis pembagian peran pada kegiatan domestik tergolong pada kategori sedang. Hal ini berarti bahwa sudah ada pembagian peran antara suami dan istri pada kegiatan rumah tangga. Pembagian peran tersebut ditunjukkan dalam hal kesehatan keluarga, pendidikan anak, dan pengelolaan keuangan keluarga.

Kegiatan sosial kemasyarakatan. Peran sosial kemasyarakatan yang dilakukan oleh istri saja adalah arisan $(67,3 \%)$. Kegiatan pengajian dilakukan oleh suami dan istri (78,6\%). Kegiatan lainnya yaitu rapat desa $(76,1)$ dan kerja bakti $(67,1)$ lebih banyak dilakukan oleh suami saja. Berdasarkan hasil pengkategorian, pembagian peran kegiatan sosial kemasyarakatan sebagian besar responden tergolong rendah, artinya bahwa suami dan istri 
kurang melakukan kerja sama dalam melakukan aktivitas tersebut.

Berdasarkan hasil analisis untuk seluruh kegiatan, pembagian peran gender pada keluarga responden masih tergolong kategori sedang. Kategori sedang artinya, sudah terdapat kerja sama antara suami dan istri dalam melaksanakan kegiatan produktif, domestik dan sosial kemasyarakatan. Namun, kerja sama belum dilakukan di setiap kegiatan karena adanya keterbatasan kemampuan, prioritas dan waktu.

\section{Kesejahteraan subjektif keluarga}

Kesejahteraan fisik. Secara umum, responden merasa puas terhadap kesejahteraan fisiknya. Hampir separuh responden merasa puas terhadap keadaan makanan keluarga, kebersihan di dalam rumah, dan ketersediaan tempat pembuangan sampah. Responden juga merasa puas (>50,0\%) terhadap keadaan kesehatan dirinya dan keluarga,cara responden dalam melakukan manajemen pekerjaan, keadaan air, kondisi tempat penampungan air dan kondisi saluran air. Namun, responden merasa tidak puas $(41,0 \%)$ terhadap kondisi dapur rumah. Hal ini dikarenakan fungsi dapur tidak hanya sebagai tempat memproduksi makanan tetapi juga tempat penyimpan alat dan bahan pertanian seperti alat penyemprot, pupuk dan pestisida. Hasil pengkategorian menunjukkan bahwa lebih dari separuh responden kesejahteraan fisiknya tinggi.

Kesejateraan ekonomi. Rata-rata, responden merasa tidak puas terhadap kondisi perekonomiannya. Hal ini ditunjukkan oleh responden yang merasa tidak puas $(>36,0 \%)$ terhadap keadaan keuangan keluarga, keadaan pendapatan keluarga, keadaan tempat tinggal, keadaan aset keluarga, kepemilikan lahan pertanian, hasil panen pertanian, kondisi usaha tani dan cara manajemen keuangan responden. Sementara itu, perasaan cukup puas pada keadaan pakaian keluarga, keadaan pakaian responden dan fasilitas dan alat-alat pertanian. Berdasarkan hasil tersebut, maka kategori kesejahteraan ekonomi responden adalah rendah.

Kesejahteraan sosial. Responden merasa tidak puas $(>48,0 \%)$ terhadap keadaan pendidikan anak, akses informasi terkait penyuluhan atau training keterampilan dan keterlibatan istri dalam penyuluhan pertanian.Sementara itu, perasaan puas $(>48,0 \%)$ dirasakan responden dalam hal keadaan pekerjaan, cara manajemen waktu, hubungan sosialnya dengan istri, saudara, orangtua dan anak dan tentangga serta dukungan sosial yang diberikan oleh pasangan, saudara, orangtua dan anak dan tetangga.

Kesejahteraan psikologi. Secara umum, responden merasakan cukup puas (>35,0\%) terhadap kesejahteraan psikologi keluarga, seperti keadaan spiritual dirinya dan keluarga, keadaan mental dirinya dan keluarga, pengetahuan responden tentang sanitasi lingkungan, cara manajemen stres dan perilaku anak. Perasaan tidak puas responden ditujukan pada pernyataan pengetahuan dan keterampilan istri yang dimiliki tentang pertanian (39,0\%). Keoptimisan keluarga terhadap masa depannya hampir menyebar rata antara kategori tidak puas, cukup puas dan puas. Sebanyak sepertiga responden merasa tidak puas dalam hal keoptimisan keluarga dalam menatap masa depan. Hasil pengkategorian menunjukkan bahwa kesejahteraan psikologis responden adalah rendah.

Kondisi pekarangan. Responden menyatakan tidak puas $(>49,0 \%)$ terhadap kondisi pekarangannya, seperti kondisi tanaman pekarangan, hasil pendapatan dari pekarangan dan variasi tanaman di pekarangan. Namun, hampir separuh responden merasa puas $(47,0 \%)$ terhadap kebersihan di pekarangannya. Berdasarkan hasil analisis, maka dapat disimpulkan bahwa kepuasan responden terhadap kondisi pekarangannya adalah rendah.

Kondisi Kebun. Sebanyak 67 persen responden tidak puas terhadap pendapatan kebun. Berdasarkan hasil wawancara dengan suami responden, ketidakpuasan ini muncul karena hasil produksi yang menurun dibandingkan musim-musim sebelumnya. Ketidakpastian iklim menyebabkan berubahnya waktu tanam dan tanaman lebih rentan terhadap hama. Berkaitan dengan penggunaan pestisida, sebanyak 48,0 persen responden merasa puas terhadap hasilnya dan cara manajemen pestisida (46,0\%). Tingkat kepuasan responden terhadap kondisi kebun adalah rendah. Secara umum, kesejahteraan subjektif sebagian besar responden berada pada kategori sedang $(68,0 \%)$. Kesejahteraan subjektif sedang artinya responden sudah merasa puas namun tidak untuk semua aspek. Ketidakpuasan responden berkaitan dengan hasil pendapatan dari kebun maupun pekarangan, kondisi kebun dan pekarangan, pengetahuan istri tentang pertanian serta akses 
dan keterlibatan istri pada penyuluhan pertanian.

\section{Pengaruh \\ Karakteristik \\ Karakteristik \\ Keluarga, Lingkungan Mikro, dan Peran Gender Terhadap Kesejahteraan Subjektif Keluarga}

Hasil analisis regresi linear berganda menunjukkan bahwa variabel karakteristik keluarga (usia istri, lama pendidikan istri, jumah anggota keluarga, pendapatan keluarga), karakteristik lingkungan rumah, permasalahan keluarga, pemeliharaan lingkungan rumah, dan peran gender menjelaskan sebesar 19,7 persen faktor-faktor yang memengaruhi kesejahteraan subjektif keluarga. Hasil analisis disajikan pada Tabel 1.

Kesejahteraan subjektif keluarga secara signifikan dipengaruhi oleh pendapatan keluarga $(\beta=0,222, \quad p<0,05)$, permasalahan keluarga $(\beta=-0,294, \quad p<0,01)$, dan pemeliharaan lingkungan mikro rumah $(\beta=0,250, \quad p<0,01)$. Peningkatan pendapatan keluarga dan pemeliharaan lingkungan mikro yang semakin baik, akan meningkatkan kesejahteraan subjektif keluarga. Sementara itu, peningkatan beban masalah keluarga dapat menurunkan tingkat kesejahteraan subjektif keluarga.

Tabel 1 Koefisien regresi untuk menganalisis pengaruh karakteristik keluarga, karakteristik lingkungan rumah, permasalahan keluarga, pemeliharaan lingkungan mikro, dan peran gender terhadap kesejahteraan subjektif keluarga

\begin{tabular}{llcc}
\hline \multicolumn{1}{c}{ Variabel } & Beta & $\mathrm{t}$ & $\mathrm{Sig}$ \\
\hline Usia istri & $-0,124$ & $-1,071$ & 0,287 \\
$\begin{array}{l}\text { Lama pendidikan istri } \\
\text { Jumah anggota }\end{array}$ & $-0,058$ & $-0,562$ & 0,575 \\
keluarga & $-0,106$ & $-0,974$ & 0,333 \\
$\begin{array}{l}\text { Pendapatan } \\
\text { keluarga }\end{array}$ & 0,222 & 2,384 & $0,019^{*}$ \\
$\begin{array}{l}\text { Karakteristik } \\
\text { lingkungan rumah }\end{array}$ & 0,093 & 0,946 & 0,347 \\
$\begin{array}{l}\text { Permasalahan } \\
\text { keluarga }\end{array}$ & $-0,294$ & $-2,872$ & $0,005^{\star *}$ \\
$\begin{array}{l}\text { Pemeliharaan } \\
\text { lingkungan mikro }\end{array}$ & 0,250 & 2,695 & $0,008^{* *}$ \\
$\begin{array}{l}\text { Peran gender } \\
\text { F }\end{array}$ & 0,087 & 0,920 & 0,360 \\
$\begin{array}{l}\text { Sig. } \\
\text { R }\end{array}$ & & & 4,028 \\
Adjusted $R$ square & & & 0,000 \\
\hline
\end{tabular}

Keterangan:

*Signifikan pada $p<0,05,{ }^{* *}$ signifikan pada $p<0,01$

\section{PEMBAHASAN}

Pendapatan merupakan faktor utama yang dikaitkan dengan kesejahteraan keluarga. Besarnya pendapatan suatu keluarga dinilai sangat menentukan kesejahteraan suatu keluarga. Keluarga minimal memiliki pendapatan cukup agar dapat memenuhi kebutuhan anggota keluarganya sehingga dapat mengurangi konflik yang dapat mengganggu keutuhan keluarga, seperti perceraian. Pendapatan yang lebih tinggi akan memungkinkan keluarga mencapai titik kepuasan yang optimum. Veenhoven (1991), diacu dalam Diener et al. (1992). menyatakan bahwa meningkatnya pendapatan akan mutlak dapat meningkatan kesejahteraannya, terutama pada masyarakat ekonomi tingkat bawah. Hasil penelitian menunjukkan bahwa negara-negara dengan pendapatan yang lebih tinggi memiliki rata-rata tingkat kesejahteraan yang lebih tinggi (Diener dan Diener, 1995). Penelitian selanjutnya menemukan bahwa meningkatnya pendapatan berpengaruh terhadap meningkatnya kesejahteraan subjektif baik pada negara miskin dan negara kaya (Diener dan Tay, 2012). Teori utilitas didasarkan pada asumsi bahwa semakin banyak maka semakin baik, artinya individu selalu menginginkan pertambahan dari pendapatannya. Namun, perlu dipahami bahwa yang penting bukan hanya memiliki pendapatan yang besar, tetapi juga berkaitan dengan cara pemanfatan pendapatan tersebut. Oleh karena itu, keluarga perlu melakukan pengelolaan atau manajemen keuangannya sehingga uang atau pendapatan yang dimiliki keluarga dapat bermanfaat secara efektif dan efisien sesuai dengan kebutuhan keluarga.

Selain pendapatan, kesejahteraan subjektif juga dipengaruhi oleh permasalahan keluarga. Permasalahan dapat bersumber dari individu maupun keluarga secara utuh. Sumber permasalahan juga dapat berasal dari dalam keluarga (internal) maupun dari lingkungan keluarga (eksternal). Permasalahan yang dialami oleh keluarga dapat menjadi tekanan atau stres bagi kehidupan keluarga. Secara umum, ekonomi merupakan permasalahan utama bagi keluarga. Tekanan ekonomi yang dialami keluarga tidak hanya memberikan dampak terhadap kesulitan dalam memenuhi kebutuhan keluarga, namun juga meluas pada kesehatan emosi dan hubungan keluarga (Elder, Conger, dan Foster, 1992).

Hasil penelitian Leske dan Jiricka (1998) menunjukkan bahwa terdapat hubungan antara kesejahteraan subjektif dengan tingkat stres 
atau tekanan dan kemampuan atau kekuatan keluarga. Tingkat stres atau tekanan yang semakin tinggi akan menurunkan tingkat kesejahteraan. Sementara itu, semakin baik kemampuan keluarga dalam mengatasi masalah, maka kesejahteraan keluarga subjektif akan semakin meningkat. Setiap keluarga unik, baik dari segi individu, sumber daya maupun cara mencapai tujuan. Permasalahan yang dihadapai keluarga juga beragam. Keberhasilan dalam menanggulangi stres ditentukan oleh sumber daya keluarga serta kemampuan dalam melakukan manajemen (Deacon dan Firebaugh, 1988). Kesejahteraan subjektif akan semakin baik jika keluarga mampu mengatasi permasalahannya. Selain itu, kerja sama antar anggota keluarga juga berpengaruh terhadap kepuasan keluarga.

Sebagai suatu ekosistem, keluarga dan lingkungannya saling berinteraksi dan bergantung satu sama lain. Perubahan pada satu sistem (manusia atau lingkungan) akan memengaruhi kehidupan sistem lainnya, sehingga diperlukan upaya untuk menjaga ekosistem tersebut. Salah satu upaya yang dilakukan adalah dengan melakukan manajemen lingkungan. Puspitawati (2013) menyatakan bahwa manajemen lingkungan adalah kemampuan memberi solusi pada pemanfaatan lingkungan dalam memenuhi kebutuhan keluarga. Manajemen lingkungan rumah berarti keluarga dituntut untuk memiliki kemampuan memberi solusi pada pemanfaatan lingkungan rumah dalam memenuhi kebutuhan keluarga. Menurut perspektif ekologi, keluarga selain mengambil manfaat dari rumah dan sekitarnya juga harus dapat memberikan timbal balik guna terciptanya keseimbangan. Hal ini didukung oleh hasil penelitian yang menunjukkan bahwa semakin baik pemeliharaan lingkungan mikro rumah yang dilakukan oleh keluarga, maka kesejahteraan subjektif keluarga semakin meningkat. Dalam penelitian ini, yang dimaksud dengan pemeliharaan lingkungan mikro yang baik adalah keluarga menjaga kebersihan rumah, mengelola pestisida agar tidak membahayakan anggota keluarga dan mengelola pekarangan.

Lingkungan rumah di lokasi penelitian, lebih banyak dilakukan oleh istri atau perempuan, karena sebagian besar termasuk ke dalam kegiatan domestik, atau sering disebut "women space". Oleh karena itu, istri atau perempuan perlu diberikan pembekalan pengetahuan baik melalui penyuluhan atau disertakan dalam kegiatan rutin di lokasi penelitian seperti pengajian dan arisan bagaimana melakukan manajemen lingkungan yang baik dan efektif. Pada banyak kasus, informasi yang diberikan kepada laki-laki atau suami melalui penyuluhan maupun diskusi tidak selalu dilanjutkan kepada istri, padahal dalam praktiknya istri lah yang melakukan kegiatan pemeliharaan lingkungan. Canbera et al. (2001), diacu dalam Montes et al. (2012) menyatakan bahwa di banyak budaya perempuan memiliki peran yang sangat penting dalam berkreasi dan perubahan pengetahuan tentang pertanian yang berkaitan dengan sumber daya produktif dan alam. Peran tersebut menjadikan perempuan memiliki lebih banyak pengetahuan lokal tentang pertanian tertentu dan praktik konservasi. Pada akhirnya, dengan kemampuan dan praktik manajemen lingkungan yang baik secara berkelanjutan dapat meningkatkan kesejahteraan subjektif keluarga dan mengurangi kemiskinan.

\section{SIMPULAN DAN SARAN}

Karakteristik lingkungan rumah responden lebih dari separuhnya udah memenuhi kriteria rumah sehat. Tingkat permasalahan keluarga termasuk rendah. Pemeliharaan lingkungan mikro yang masih kurang baik adalah berkaitan dengan kebersihan dan kesehatan lingkungan rumah. Hasil menunjukkan sudah ada kerja sama yang baik antara suami dan istri dalam melakukan kegiatan usaha tani dan rumah tangga. Sementara itu, kerja sama suami dan istri pada kegiatan sosial kemasyarakatan masih kurang.

Kesejahteraan subjektif keluarga yang termasuk tinggi adalah dimensi fisik dan sosial. Kesejahteraan subjektif yang termasuk kategori sedang adalah psikologi, pekarangan dan kebun. Sementara itu, kesejahteraan dimensi ekonomi termasuk kategori rendah. Secara umum, kesejahteraan subjektif keluarga termasuk kategori sedang, artinya responden sudah merasa puas namun tidak untuk semua aspek. Kesejahteraan subjektif keluarga dipengaruhi oleh pendapatan keluarga, permasalahan keluarga, dan pemeliharaan lingkungan mikro rumah.

Berdasarkan hasil analisis, untuk meningkatkan kesejahteraan subjektif keluarga disarankan perlu adanya penguatan kerja sama antara suami dan istri dalam kegiatan usaha tani dan domestik, sehingga istri dapat berkontribusi lebih baik terhadap pendapatan keluarga. Selain itu, dengan keterlibatan suami di kegiatan domestik, beban istri akan lebih ringan dan penyelesaian pekerjaaan akan lebih efisien. Penelitian ini juga menyarankan perlunya penyuluhan manajemen lingkungan 
terutama berkaitan dengan pengelolaan sampah rumah tangga dan manajemen pestisida yang tepat dan tidak membahayakan keluarga dan lingkungan.

\section{UCAPAN TERIMA KASIH}

Penulis mengucapkan terima kasih kepada Tim Gender-CRSP yang merupakan bagian dari projek Integrated Pest Management Collaborative Research Support Program (IPMCRSP) tahun 2012, kerja sama antara USAID, Clemson University-USA, dan Virginia-Tech University-USA dengan Institut Pertanian Bogor. Artikel ini menggunakan sebagian data dari penelitian tersebut.

\section{DAFTAR PUSTAKA}

Adriyani, R. (2006). Usaha pengendalian pencemaran lingkungan akibat penggunaan pestisida pertanian. Jurnal Kesehatan Lingkungan, 3(1), 95-106.

Bertham, Y. H., Ganefianti, D. W. \& Andani A. (2011). Peranan perempuan dalam perekonomian keluarga dengan memanfaatkan sumberdaya pertanian. Jurnal Agrisep 10(1), 138-153.

[BPS] Badan Pusat Statistik. (2013). Statistik Daerah Kecamatan Cipanas Tahun 2013. Cianjur, ID: BPS.

Deacon, R. E. \& Firebaugh. (1988). Family resource management principle and aplication 2nd ed. London Sidney, UK: Allyn and Bacon, Inc.

Diener, E. \& Diener, M. (1995). Cross-curtural correlates of life satisfaction and selfesteem. Journal of Personality and Sosial Psychology, 68, 653-663.

Sandvik, E., Pavot, W., \& Fujita, F. (1992). Extraversion and subjective wellbeing in a U.S. national probability sample. Journal of Research in Personality, 26, 205-215.

\& Tay, L. (2013). Rising income and the subjective well-being of nations. Journal of Personality and Social Psychology, 104 (2), 267-276.

Elder, G. H. Jr, Conger, R. D., \& Foster, E. M. (1992). Family under economic pressure. Journal of Family Issues, 13(1). 5-37.

Elizabeth, R. (2008). Peran ganda wanita tani dalam mencapai ketahanan pangan rumah tangga di pedesaan. Jurnal Iptek Tanaman Pangan, 3(1), 59-68.
Hurlock, E. B. (1998). Perkembangan anak. Jakarta, ID: Erlangga.

Leske, J. S., \& Jiricka, M. K. (1998). Impact of family demands and family strengths an capabilities on family well-being and adaptation after critical injury. American Journal of Critical Care, 7(5), 383-392.

Marzali, U. (2006). Struktural fungsionalisme. Jurnal Antropologi Indonesia 30(2), $127-$ 137.

Montes I. G., Emery M., \& Baca E. F. (2012). Why gender matters to ecological management and poverty reduction (Chapter 4). Integrating ecology and poverty reduction. Springer, 39-59.

Priyddi U. (2005). Tingkat kesetaraan gender pada usaha tani padi di Kecamatan Mlati Kabupaten Sleman. Jurnal Fenomena, 3 (2), 146-159.

Purnawati, R. (2009). Kontribusi sumber daya manusia petani perempuan dalam kehidupan pertanian di desa. Jurnal DIMENSIA, 3(2), 15-32.

Puspitasari, N., Puspitawati, H., \& Herawati, T. (2013). Peran gender, kontribusi perempuan dan kesejahteraan keluarga petani holtikultura. Jurnal Ilmu Keluarga \& Konsumen, 6(1), 10-19.

Puspitawati, H. (2006). Pengaruh faktor keluarga, lingkungan teman dan sekolah terhadap kenakalan pelajar di sekolah lanjutan tingkat atas (SLTA) di Kota Bogor (disertasi). Sekolah Pascasarjana, Institut Pertanian Bogor, Bogor.

\& Fahmi, S. A. (2008). Analisis pembagian peran gender pada keluarga petani. Jurnal IImu Keluarga \& Konsumen, 1(2), 24-33.

Suryahadi, Sarma, M., Hartoyo, Trikoesoemaningtyas, \& Herawati, $T$. (2009). Kaji tindak model pengentasan kemiskinan melalui pemberdayaan gender dan keluarga berbasis pertanian dan keunikan agroekosistem pedesaan (laporan). Jakarta, ID: Dirjen DiktiKemendikbud.

(2013). Ekologi keluarga: Konsep dan lingkungan. Bogor, ID: IPB Press.

Sari, A. I., Purnomo, S. H., \& Rahayu, E.T. (2009). Sistem pembagian kerja, akses dan kontrol terhadap sumber daya ekonomi dalam keluarga peternak rakyat sapi potong di Kabupaten Grobogan. Sains Peternakan, 7(1), 18-26. 
Skogrand, L., Johnson, A. C., Horrocks, A. M., \& DeFrain, J. (2010). Financial management practices of couples with great marriages. Journal of Family Economy, 32, 27-35.
Soesilo, Y. H., Sunan, A., \& Kaluge, D. (2007). Penyebab kemiskinan masyarakat petani (studi di Dusun Ngebrong, Desa Tawangsari, Kecamatan Pujon, Kabupaten Malang). Journal of Indonesian Applied Economics, 1(1), 57-67. 